\title{
Labyrinthe
}

28 | 2007 (3)

Des Juifs contre l'émancipation

\section{Actualité Juive}

$\mathrm{n}^{\circ} 1012,7$ février 2008, p. 51

\section{OpenEdition}

Journals

\section{Édition électronique}

URL : http://journals.openedition.org/labyrinthe/3392

DOI : $10.4000 /$ labyrinthe.3392

ISSN : 1950-6031

Éditeur

Hermann

Édition imprimée

Date de publication : 21 décembre 2007

ISBN : 978-2-9526131-5-6

\section{Référence électronique}

«Actualité Juive », Labyrinthe [En ligne], 28 | 2007 (3), mis en ligne le 10 février 2008, consulté le 24 avril 2019. URL : http://journals.openedition.org/labyrinthe/3392 ; DOI : 10.4000/labyrinthe.3392

Ce document a été généré automatiquement le 24 avril 2019

Propriété intellectuelle 


\section{Actualité Juive}

$\mathrm{n}^{\circ} 1012,7$ février 2008, p. 51

1 «[...] Pierre Savy et David Schreiber ont construit un remarquable numéro de la revue Labyrinthe, d'autant plus stimulant que les contributeurs ont à la fois une bonne maitrise des sources juives traditionnelles et une rigueur scientifique irréprochable. Leur questionnement est le suivant: qu'est-ce qui a motivé le fait que des penseurs ou des autorités religieuses juives aient, dès l'époque des Lumières elles-même, récusé l'émancipation? Et pourquoi, dans un Occident où l'État perd de plus en plus sa centralité, assiste-t-on à un retour de la pensée critique vis-à-vis de celle-ci ? [...] » 